\title{
PENGARUH BUDAYA ORGANISASI TERHADAP MUTU PENDIDIKAN
}

\author{
Minatul Anggreni \\ Prodi Ekonomi Syariah Institut Agama Islam Negeri Ponorogo \\ Email: minatul2000@gmail.com
}

Website : https://jurnal.uin-antasari.ac.id/index.php/ptkpend/index

Received: 17 Oktober 2020; Accepted: 29 Desember 2020; Published: 1 Januari 2021

\begin{abstract}
The high level of competition in the world of education in Indonesia demands that educational institutions have added value to be chosen and trusted by the community. Added value can be applied as a quality education where educational institutions guarantee the satisfaction of the community as consumers. Educational institutions must be built with an organizational culture that provides strength for the implementation of the quality education process. This study aims to determine and explain the influence of organizational culture on the quality of education. The method used in this research is quantitative descriptive method, the samples used were obtained from 20 students from various study programs and universities in Indonesia who were taken randomly through their friendship contacts from the researcher Whatsapp application. The data collection technique used was interviews. The results showed that organizational culture is very influential and important in the world of education. This is indicated by the high percentage reaching $100 \%$. And also by joining an organization will have a good impact on academic scores, shown by $70 \%$ of students responding to a good impact, $5 \%$ having a bad impact, $25 \%$ having no impact. The opinion of 20 students said that the influence of organizational culture is very important and influential and has a good impact in the world of education.
\end{abstract}

Keywords: Organizational Culture; Educational Institutions; Quality of Education

\begin{abstract}
ABSTRAK
Banyaknya persaingan di dunia pendidikan di Indonesia menuntut lembaga pendidikan memiliki nilai tambah untuk dipilih dan dipercaya oleh masyarakat. Nilai tambah dapat di terapkan sebagai kualitas pendidikan dimana lembaga pendidikan memberikan jaminan kepuasan masyarakat sebagai konsumen. Lembaga pendidikan harus dibangun dengan budaya organisasi yang memberikan kekuatan untuk pelaksanaan proses kualitas pendidikan. Penelitian ini bertujuan untuk mengetahui dan menjelaskan pengaruh budaya organisasi terhadap mutu pendidikan. Metode yang digunakan dalam penelitian ini adalah metode deskriptif kuantitatif, sampel yang digunakan diperoleh dari 20 mahasiswa dari berbagai program studi dan universitas di Indonesia yang diambil secara acak melalui kontak pertemanan dari aplikasi Whatsapp peneliti. Teknik pengumpulan data yang digunakan adalah wawancara. Hasil penelitian menunjukkan bahwa budaya organisasi sangat berpengaruh dan penting dalam dunia pendidikan. Hal ini ditunjukkan dengan tingginya presentase mencapai $100 \%$. Dan juga dengan mengikuti organisasi akan berdampak baik pada nilai akademik, ditunjukkan dengan $70 \%$ mahasiswa merespon berdampak baik, 5\% berdampak buruk, 25\% tidak berdampak. Pendapat dari 20
\end{abstract}


mahasiswa mengatakan bahwa pengaruh budaya organisasi sangat penting dan berpengaruh serta berdampak baik dalam dunia pendidikan.

Kata kunci: Budaya Organisasi; Lembaga Pendidikan; Mutu Pendidikan

\section{PENDAHULUAN}

Lingkungan dunia yang mengalami perubahan yang signifikan dapat menghambat pertumbuhan suatu negara. Perubahan-perubahan yang terjadi misalnya kemajuan ilmu pengetahuan dan teknologi, sumber daya manusia, dan globalisasi. Masyarakat memiki peranan penting dalam mengatur kegiatan pemerintah dan pendidikan. Maka dari itu pentingnya campur tangan masyarakat dalam membuat beberapa aturan. Perlu adanya untuk menumbuhkan keseimbangan antara keahlian pemerintah dengan lembaga pendidikan yang berada di luar organisasi. Pengambilan keputusan sangat dibutuhkan ketika ada sebuah kegiatan. Hal tersebut memerlukan adanya manajemen strategi yaitu menyusun dan menerapkan strategi yang fokus terhadap tujuan organisasi, mengembangkan aturan dan rencana dalam sebuah organisasi, dan membagi sumber daya manusia guna untuk menerapkan aturan dan perencanaan tujuan dalam sebuah organisasi serta mengevaluasi hasilnya.

Lembaga pendidikan haruslah memiliki nilai tambah (value added) yang dapat menarik kepercayaan masyarakat untuk memilihnya. Hal tersebut dikarenakan banyaknya persaingan antar lembaga pendidikan di Indonesia. Selain itu lembaga pendidikan harus dapat membaca daya tarik masyarakat dalam hal perubahan pendidikan, kemudian untuk memenuhi kebutuhan pendidikan yang dinginkan oleh masyarakat.

Di zaman modern seperti sekarang ini banyak didapati beberapa perubahan yang mengharuskan manusia untuk memiliki pengetahuan yang luas dalam menghadapi tantangan perubahan di masa yang akan datang. Perubahan tersebut diantaranya perubahan ekonomi, sosial budaya, dan ilmu pengetahuan dan teknologi.
Sejalan dengan pendapat (Umaedi et al., 2011) yang mengungkapkan bahwa guna mempersiapkan sumber daya manusia yang berkualitas dan siap untuk menghadapi tantangan perubahan di masa yang akan datang, baik individu maupun kelompok harus memiliki pendidikan.

Agar mampu menghadapi tantangan masa depan yang lebih baik dan sejahtera. Baik untuk diri sendiri maupun orang banyak dengan menjadikan pendidikan sebagai investasi bagi manusia di kehidupan berikutnya. Tentunya perlu dikelola dan siapkan yang mencakup segala aspek baik secara makro maupun mikro. Selain itu tujuan visi dan misi juga harus kuat jelas.

Organisasi adalah sekumpulan kelompok manusia yang didalamnya saling bertukar pendapat guna untuk mencapai tujuan bersama. Organisasi pendidikan merupakan perkembangan organisasi dalam dunia pendidikan yang di dalamnya menjadi substansi pemahaman tersendiri dalam ilmu pengetahuan.

Dari pernyataan tersebut, dapat ditarik kesimpulan bahwa pendidikan yang berperan sebagai sumber pendorong dan alat penggagas pendidikan, organisasi yang terdapat dalam sebuah pendidikan harus memiliki fungsi yang signifikan dalam mencapai tujuan pendidikan. Budaya organisasi dalam tatanan pendidikan di Indonesia perlu di realisasikan. Hal ini bertujuan agar generasi penerus bangsa terutama anak didik tumbuh menjadi generasi yang cerdas dan memiliki karakter jiwa pemimpin yang siap untuk menghadapi tantangan kehidupan di masa yang akan datang.

\section{Budaya Organisasi}

Sebelum membahas apa itu budaya organisasi, kita perlu mengetahui mengenai maksud dari organisasi. Seperti yang dikemukakan Thompson (dalam Thoha, 1992) menyatakan bahwa "an 
roganization is a highly rationalized and impersonal integration of a large member of specialists cooperating to achieve some announched speciific objectif".

Sedangkan Weber (dalam Thoha, 1992) mengemukakan bahwa dalam berorganisasi mempunyai beberapa komponen-komponen yaitu sebagai berikut:

1. Organisasi adalah lembaga sosial. Dimana didalamnya terdapat interaksi antar individu, kelompok, dan lingkungannya yang saling berkaitan dan berpengaruh satu sama lain. Saling menghargai pendapat guna mencegah berbagai perselisihan.

2. Organisasi dengan batas-batas tertentu (bounderies). Dengan begitu, hubungan interaksi individu satu dengan individu yang lainnya tidak didasarkan atas kemauan mereka sendiri. Melainkan apa yang mereka lakukan terdapat batasan aturan tertentu.

3. Organisasi merupakan suatu perkumpulan tata aturan. Dengan organisasi yang memiliki aturan tersebut dapat dijadikan pembeda antara suatu organisasi satu dengan lainnya. Peraturan atau tata aturan ini tidak mungkin ada begitu saja, namun karena adanya anggota organisasi yang saling berkomunikasi dan bekerja sama untuk membuat tata aturan dalam organisasi tersebut.

4. Organisasi merupakan suatu elemen hubungan kerja yang tersusun atas hak, kewajiban, wewenang, tanggung jawab, dan pembagian tugas kerja untuk melakukan suatu pekerjaan yang memiliki fungsi tertentu. Nama lain dari komponen ini adalah heirarki. Dalam heirarki ini terdapat tingkatan atau wewenang jabatan dari yang paling tinggi yaitu pemimpin dan paling rendah adalah bawahan.

Dari pendapat diatas diketahui bahwa organisasi adalah kumpulan kelompok kerja yang memiliki tujuan sama bersifat pada satu kesatuan, tersusun atas hak, kewajiban, wewenang, fungsi dan tanggung jawab yang saling berhubungan antara yang satu dengan yang lainnya.

(Robbins \& Judge, 2008) mengartikan budaya organisasi adalah suatu pembeda antara sebuah organisasi satu dengan organisasi lainnya yang memiliki karakteristik yang berbeda-beda. Menurut (Robbins \& Judge, 2008) , budaya organisasi tentunya memiliki pemahaman yang berbeda-beda. Maka dari itu, diharapkan adanya kesatuan perbedaan dalam memahami arti penting dari budaya organisasi. (Hakim \& Kusdiyanto, 2010) Dalam budaya organisasi komunikasi sangat diperlukan dalam meyakinkan dan mempengaruhi aspek kehidupan orang lain. Sehingga budaya organisasi mampu mematahkan akibat organasi yang berubah ketika hal tersebut sudah terencana dengan sebaik-baiknua. Budaya organisasi juga dapat sebagai pendukung bahkan penghambat dalam sebuah proses perubahan organisasi.

Kemudian (Jumadi, 2005) menjelaskan tipe-tipe budaya organisasi dibagi menjadi tiga, yaitu :

1) Budaya bersifat positif (budaya yang mendukung proses peningkatan mutu pendidikan)

2) Budaya bersifat negatif (budaya yang menghambat proses peningkatan mutu pendidikan)

3) Budaya yang bersifat netral (budaya yang tidak mendukung maupun tidak menghambat proses mutu pendidikan)

Dari tipe-tipe budaya organisasi tersebut menurut (Jumadi, 2005), maka budaya organisasi memiliki fungsi sebagai

a. Memajukan para anggotanya untuk mengidentifikasi diri dan menumbuhkan keahlian dalam organisasi secara keseluruhan.

b. Memotivasi para anggotanya untuk bekerja sama dengan kelompoknya dan bukan hanya mementingkan kepentingan pribadi. 
c. Memfokuskan keterlibatan para anggotanya dengan organisasi dalam memperoleh hasil yang diinginkan.

d. Semakin kuat organisasi mudah melakukan pengawasan.

Dari penjabaran tersebut dapat diketahui bahwa budaya organisasi dalam instusi pendidikan adalah suatu paradigma yang membentuk sebuah tingkatan, kepercayaan dan keinginan yang muncul dari diri sendiri berkaitan dengan pekerjaanya untuk mendapatkan lulusan yang berkualitas dan kompetentif. Seperti yang kita tahu didalam suatu budaya organisasi ada yang formal dan nonformal. Tentunya jika dilakukan dengan baik akan menumbuhkan sistem organisasi yang efektif. Selanjutnya akan menjadikan sistem yang sehat. Dalam hal ini suatu instusi haruslah membuat agenda agar jalinan dalam sekolah maupun luar sekolah tetap berjalan dengan baik. Selain itu, pimpinan dalam sekolah agar mengarahkan. Baik guru maupun murid saling membantu dengan harapan munculnya sikap amanah di semua kegiatan.

\section{Lembaga Pendidikan}

Lembaga Pendidikan adalah suatu wadah yang digunakan untuk melangsungkan suatu proses pembelajaran pendidikan dengan tujuan untuk merubah perilaku agar menjadi lebih baik lagi. Setiap lembaga pendidikan dibagi menjadi 2 yaitu formal dan informal. Berdasarkan tersebut orang tua dapat menilai hal apa yang akan ditimbulkan anak ketika berada di lingkup lembaga pendidikan tersebut. Lembaga pendidikan berpengaruh terhadap mutu anak didik melalui karakter, tingkah laku, mindset, dan lain-lain. Lembaga pendidikan dapat dibagi menjadi 3, yaitu :

\section{Lembaga Pendidikan Keluarga}

Pendidikan keluarga merupakan wadah atau tempat pendidikan pertama bagi seorang anak. Maksud pertama ialah karena di keluarga inilah tempat yang dimana anak mendapat bimbingan atau ajaran pendidikan untuk pertama kalinya. Orang tua berperan sebagai pembimbing atau dan anak memiliki peran sebagai yang dibimbing. Tugas keluarga disini yaitu sebagai peletak dasar-dasar untuk pertumbuhan anak agar tumbuh menjadi anak yang memiliki perilaku yang baik.

Melalui pendidikan lingkungan keluarga inilah, perlu didirikan pendidikan yang demokratis, adil, tanggungjawab, tolong menolong, kasih mengasihi, sayang menyayangi. Anak menjadikan orang tua sebagai panutan, maka orang tua harus menjadi panutan yang baik dengan memberi contoh hal-hal yang baik untuk anaknya.

Tugas lembaga pendidikan keluarga, yaitu

a. Pengalaman pertama masa kanakkanak

Dimulai dari bimbingan orang tua terhadap anak tersebut. Kehidupan anak sangat tergantung dari bagaimana tingkah laku orang tua.

b. Menjamin kehidupan emosional

Emosional anak harus benar-benar diperhatikan, meskipun mendapat masalah kecil, emosional anak biasanya susah terkontrol. Perhatian, cinta, dan kasih saying orang tua sangat dibutuhkan dalam mengatur emosi anak.

c. Menanamkan dasar pendidikan moral Untuk memulai suatu proses kehidupan, anak biasanya akan meniru tingkah laku yang didapat dari orang tua. Jika moral diajarkan baik maka anak akan berperilaku baik, dan jika yang diajarkan moral yang buruk maka anak juga mengikuti perilaku buruk.

d. Sebagai dasar pendidikan sosial

Pendidikan sosial yang dimaksud yaitu untuk membimbing, mendidik dan membangun individu ditengah masyarakat agar nanti dapat berperilaku baik. Misalnya gotong royong, tolong menolong, dan peduli terhadap sesama.

e. Peletakan dasar-dasar keagamaan

Dari kecil anak mulai diperkenalkan terhadap Tuhannya, mulai dilatih 
mengenal agama dan mulai melakukan ibadah sejak dini.

Dari pernyataan tersebut dapat diketahui bahwa orang tua memiliki peranan yang sangat penting dalam membentuk karakteristik seorang anak. Dan keluarga harus bisa menjadi tempat yang paling nyaman bagi kehidupan anak tersebut.

\section{Lembaga Pendidikan Sekolah}

Lembaga pendidikan sekolah ini merupakan lembaga pendidikan yang kedua setelah keluarga. Lembaga ini muncul akibat orang tua yang memiliki kemampuan terbatas dalam membimbing anaknya. Guna untuk membantu pembimbingan tersebut maka diserahkanlah anaknya kepada orang yang memilki pengetahuan yang lebih luas yaitu kepada guru(Hasbullah, 2003). Sekolah juga merupakam tempat untuk memperoleh pendidikan dan mengembangkan skill atau bakat terpendam anak.

Menurut (Gazali, 2013) ada beberapa ciri dari lembaga pendidikan sekolah ini, diantaranya:

a. Memiliki tingkatan pendidikan yang dimulai dari yang paling rendah menuju tingkatan yang lebih tinggi.

b. Memiliki usia anak didik yang sama pada suatu jenjang pendidikan tertentu.

c. Berlangsungnya sebuah pendidikan masa nya tidak sama, tergantung bagaimana program pendidikan yang dipilihnya.

d. Berisi teori atau ilmu pengetahuan dalam melakukan pembelajaran pendidikan.

e. Kualitas pendidikan dijadikan patokan untuk pengembangan kebutuhan dimasa yang akan datang. Peran lembaga pendidikan, yaitu :

- Tempat untuk bergaul

- Tempat untuk belajar mentaati tata tertib

- Mempersiapkan anak didik untuk menjadi anggota masyarakat yang berguna bagi agama, bangsa dan negara(Idris, 1981)

Dengan mengetahui karakteristik dan peranan lembaga pendidikan, maka sekolah diharapkan mampu untuk mencetak anak-anak yang berbakat dan berprestasi.

\section{Lembaga Pendidikan Masyarakat}

(Barnadib,

1986)Pendidikan masyarakat merupakan lingkungan pendidikan ketiga setelah keluarga dan sekolah. Masyarakat merupakan sekelompok manusia yang tinggal pada suatu daerah tertentu yang memiliki kesadaran yang sama dalam menghadapi suatu tantangan dan menumbuhkan kesatuan dalam melakukan keberlangsungan hidupnya. Pendidikan masyarakat ini berfungsi untuk melengkapi pendidikan keluarga dan pendidikan sekolah.

Partisipasi masyarakat sangat diharapkan untuk membantuk mencerdaskan anak bangsa. Ciri-ciri lembaga pendidikan masyarakat adalah sebagai berikut :

a. Pelaksanaannya dilakukan di luar pendidikan lembaga sekolah.

b. Yang mengikuti pendidikan ini biasanya orang yang sudah tidak melanjutkan sekolah.

c. Tidak adanya tingkatan pendidikan dan untuk waktu pelaksanaannya bebas.

d. Beraneka ragam peserta didik dalam masyarakat ini.

e. Mengarahkan pendidikan secara manual melalui beberapa evaluasi yang menyeluruh dan logis.

f. Memiliki isi pendidikan yang mudah dilaksanakan.

g. Dibutuhkannya keahlian kerja guna untuk memperbaiki tingkat kehidupan. (Tanlain, 1989)

Oleh karena itu, masyarakat diharapkan mampu untu membantu mencerdaskan kehidupan berbangsa. Sebagai lembaga pendidikan setelah keluarga dan sekolah, masyarakat dapat 
digunakan untuk menumbuhkan dan memaksimalkan kemampuan diri.

\section{Mutu Pendidikan}

Dalam (KBBI, 2016), mutu dapat diartikan baik atau buruk dan taraf atau kadar kecerdasan. Pendidikan yang berjalan dengan lancar dan efisien dapat dikatakan sebagai pendidikan yang bermutu. (Suryadi \& Tilaar, 1993) menyatakab bahwa "Mutu pendidikan merupakan kemampuan sistem pendidikan yang diarahkan secara efektif untuk meningkatkan nilai tambah faktor input agar menghasilkan output yang setinggitingginya. Indikator atau kriteria yang dapat dijadikan tolak ukur mutu pendidikan yaitu hasil akhir pendidikan". Standar pendidikan merujuk pada Peraturan Pemerintah No 19 Tahun 2005 yang isinya mengemukakan tentang Standar Pendidikan Nasional (SPN), yang diantaranya :

1) Standar Isi

2) Standar Proses

3) Standar Kompetensi Lulusan

4) Standar Pendidikan dan Tenaga Kependidikan

5) Standar Sarana dan Prasarana

6) Standar Pengelolaan

7) Standar Pembiayaan

8) Standar Penilaian Pendidikan

\section{METODE PENELITIAN}

Dalam analisis ini saya menggunakan metode angket atau kuisioner dalam pengumpulan data. Kuisioner diberikan melalui jejaring sosial chat aplikasi WhatsApp kepada subjek penelitian yang mana subjek penelitian berupa sampel yang dipilih melalui random sampling. Definisi sampel adalah sebagin contoh dari jumlah yang dimiliki oleh suatu populasi (Sugiyono, 2008 : 116) sedangkan sampling adalah teknik dalam mengambil contoh sampel. Random sampling menurut Sugiyono adalah "teknik pengambilan sampel dimana semua individu dalam populasi, baik individu maupun bersama diberi kesempatan yang sama untuk dipilih sebagai anggota sampel". Pengambilan random sampling pada penelitian ini berdasarkan daftar kontak teman pada aplikasi WhatsApp peneliti.

Data yang diperoleh kemudian di olah dengan metode deskriptif kuantitatif, dalam metode ini pengambilan sampel digunakan untuk kesesuaian pada data kemudian disesuaikan dengan metodemetode yang digunakan. Hal ini sejalan dengan pendapat (Sugiyono, 2003 : 14) bahwa definisi kuantitatif adalah data yang berisi angka didalamnya. Dan penelitian kuantitatif merupakan penelitian dengan memperoleh data yang memiliki bentuk skema atau gambar.

\section{HASIL DAN PEMBAHASAN}

Berikut adalah hasil dan pembahasan yang saya peroleh setelah melakukan penelitian yang didalamnya terdapat 20 orang partisipan. Gambaran dari partisipan dapat kita lihat melalui jenis kelamin dan lokasi provinsi perguruan tinggi.

Tabel 1 Deskripsi Partisipan

\begin{tabular}{|c|c|c|}
\hline Karakteristik & Frekuensi & Persentase \\
\hline Jenis Kelamin & 10 & $50 \%$ \\
\hline Laki-laki & 10 & $50 \%$ \\
\hline Perempuan & 1 & $5 \%$ \\
\hline Lokasi Provinsi & \multicolumn{1}{|l|}{} \\
\hline Jawa Barat & $10 \%$ \\
\hline Jawa Tengah & 2 & $10 \%$ \\
\hline $\begin{array}{c}\text { Daerah Istimewa } \\
\text { Yogyakarta }\end{array}$ & 2 & $75 \%$ \\
\hline Jawa Timur & 15 &
\end{tabular}

Tabel 2 Respon Partisipan

\begin{tabular}{|c|c|c|}
\hline $\begin{array}{l}\text { Respon } \\
\text { Partisipan }\end{array}$ & Frekuensi & Persentase \\
\hline \multicolumn{3}{|c|}{$\begin{array}{l}\text { Apakah Budaya Organisasi Berpengaruh Terhadap } \\
\text { Mutu Pendidikan? }\end{array}$} \\
\hline Berpengaruh & 20 & $100 \%$ \\
\hline $\begin{array}{c}\text { Tidak } \\
\text { Berpengaruh }\end{array}$ & 0 & $0 \%$ \\
\hline $\begin{array}{l}\text { Apakah Budaya } \\
\text { Pendidikan? }\end{array}$ & Organisasi & nting Untuk \\
\hline Penting & 20 & $100 \%$ \\
\hline Tidak Penting & 0 & $0 \%$ \\
\hline \multicolumn{3}{|c|}{$\begin{array}{l}\text { Apakah Dengan Mengikuti Organisasi akan } \\
\text { Berdampak Pada Nilai Akademik ? }\end{array}$} \\
\hline $\begin{array}{l}\text { Berdampak } \\
\text { Baik }\end{array}$ & 14 & $70 \%$ \\
\hline Berdampak & 1 & $5 \%$ \\
\hline
\end{tabular}




\begin{tabular}{|c|c|c|}
\hline Buruk & & \\
\hline $\begin{array}{c}\text { Tidak } \\
\text { Berdampak }\end{array}$ & 5 & $25 \%$ \\
\hline
\end{tabular}

Berdasarkan analisa yang saya peroleh dari tabel tersebut, dapat diambil pernyataan bahwa budaya organisasi sangat berpengaruh dan penting di dalam dunia pendidikan. Hal ini ditunjukkan dengan tingginya persentase yaitu mencapai $100 \%$. Dan juga dengan mengikuti organisasi akan berdampak baik pada nilai akademik, hal ini ditunjukkan $70 \%$ merespon berdampak baik, 5\% berdampak buruk, 25\% tidak berdampak. Pendapat dari 20 partisipan mengatakan bahwa pengaruh budaya rganisasi sangat penting dan berpengaruh serta berdampak baik di dalam dunia pendidikan.

Dalam budaya organisasi diwajibkan kepada setiap individu harus tetap aktif dan dapat berkembang dengan baik. Pola pikir setiap individu diharapkan agar setiap anggota dalam sebuah organisasi dapat berkembang sesuai dengan perubahan zaman. Selain itu, bagi partisipan organisasi juga melatih jiwa kepemimpinan. Berbudaya organisasi merupakan langkah yang tepat dimana jiwa kepemimpinan individu bisa diasah, yaitu dengan mengedepankan kepentingan bersama daripada kepentingan pribadi. Berlatih bagaimana mengambil keputusan dengan bijak tanpa merugikan pihak manapun.

Berbudaya organisasi sangatlah penting dan juga berpengaruh terhadap pendidikan serta sumber daya manusia. Karena organisasi merupakan perkumpulan kerja dengan tujuan sama, dengan visi misi yang nantinya sangat berguna untuk menunjang mutu pendidikan melalui sumber daya yang terpemimpin. Namun tidak sembarang dalam memilih organisasi, harus mengetahui terlebih dahulu visi dan budaya organisasi tersebut, apakah benarbenar baik dan berdampak positif bagi yang mengikutinya atau sebaliknya.

\section{PENUTUP}

Berdasarkan dari hasil analisis data yang telah saya lakukan dapat disimpulkan bahwa visi dan budaya organisasi sangat berpengaruh terhadap mutu pendidikan. Diantaranya adalah menambah pengetahuan, menambah wawasan, melatih jiwa kepemimpinan, belajar membagi waktu, belajar bekerjasama dengan tim, meningkatkan kemampuan di publik dan lain sebagainya.

Bentuk visi dan budaya organisasi yang seperti itu menjadikan individu semakin bersemangat. Optimis dalam berorganisasi karena individu merasa bahwa mereka mendapat ilmu lebih dalam berorganisasi. Hal tersebut tidak akan didapat jika seseorang individu hanya mengandalkan pendidikan akademik. Meskipun berorganisasi juga bukan hal yang mudah, namun dengan berbudaya organisasi dapat membuat individu menjadi lebih baik serta menunjang perkembangan sumber daya manusia.

Dan tidak dilupakan juga bahwa melalui pendidikan lingkungan sekolah, lingkungan keluarga maupun lingkungan masyarakat juga sangatlah berguna untuk membentuk karakteristik anak-anak. Dan diharapkan melalui lingkungan pendidikan tersebut dapat mencetak generasi penerus bangsa yang unggul, aktif, cerdas, kreatif dan inovatif.

\section{DAFTAR PUSTAKA}

Barnadib, sutari imam. (1986). Pengantar Ilmu Pendidikan Sistematis. FIP IKIP.

Gazali, M. (2013). Optimalisasi Peran Lembaga Pendidikan Untuk Mencerdaskan Bangsa. Jurnal AlTa'dib, 6(9), 1689-1699.

Jumadi., (2005).. (2005). Peranan Kultur Sekolah Terhadap Kinerja Guru, Motivasi Berprestasi Dan Prestasi Belajar Ipa Siswa . Belajar, P., \& Siswa, I. P. A 217-228.

Hakim, L., \& Kusdiyanto. (2010). Analisis Pengaruh Budaya Organisasi Terhadap Kinerja Karyawan. Jurnal Ilmu Ekonomi \& Manajemen, 1, 53- 
77.

Hasbullah. (2003). Dasar-Dasar Ilmu Pendidikan (Umum dan Agama Islam). PT Raja Grafindo Pesada.

Idris, Z. (1981). Dasar-Dasar Kependidikan. Angkasa.

Ihsan, F. (1995). Dasar-Dasar Kependidikan. Rineka Cipta.

KBBI. (2016). Kamus Besar Bahasa Indonesia ( KBBI ). In Kementerian Pendidikan dan Budaya.

Robbins, S. P., \& Judge, T. A. (2008). Perilaku organisasi edisi ke-12. In Chemical and Petroleum Engineering.
Sugiyono. (2003). Metode Penelitian Administrasi. Alfabeta.

Sugiyono. (2008). Metode Penelitian Pendidikan: (pendekatan kuantitatif, kualitatif dan $R \& D$ ). Alfabeta.

Suryadi, \& Tilaar. (1993). Analisis Kebijakan Pendidikan-Suatu Pengantar. Remaja Rosdakarya.

Tanlain, W. (1989). Dasar-Dasar Ilmu Pendidikan. Gramedia.

Thoha, M. (1992). Perilaku Organisasi : CV Rajawali.

Umaedi, Hadiyanto, \& Siswantari. (2011). manajemen berbasis sekolah. Universitas Terbuka. 